\title{
STREPTOCOCCAL ANTIFIBRINOLYSIN IN RHEUMATOID ARTHRITIS AND SPONDYLITIS ANKYLOPOIETICA
}

\author{
BY C. BRUCE PERRY \\ From the Department of Medicine, University of Bristol.
}

THE presence of agglutinins to hæmolytic streptococci in the blood of many patients with rheumatoid arthritis was first reported by Cecil, Nicholls and Stainsby (1931). This phenomenon has been confirmed since by Dawson, Olmstead and Boots (1932), Nicholls and Stainsby (1933), Keefer, Myers and Oppel (1933), Cox and Hill (1934), Blair and Hallman (1935), McEwen, Chasis and Alexander (1935), and Neil and Hartung (1937); but the incidence of positive agglutination reactions varied from 85 per cent. (Blair and Hallman) to 30 per cent. (Neil and Hartung). Dawson, Olmstead and Boots (1932) suggested that the property of agglutinating hæmolytic streptococci is related to the age of the patient and the duration of the disease, and this was confirmed by Nicholls and Stainsby (1933). However, since all patients with rheumatoid arthritis do not show a positive agglutinin reaction, the exact significance of the finding is open to discussion. Attempts have been made to demonstrate the presence of other antibodies to the hæmolytic streptococcus in such patients. McEwen, Chasis and Alexander (1935) reported positive precipitin reactions between sera of patients with rheumatoid arthritis and various groups of hæmolytic streptococci, and Neil and Hartung (1937) found that the precipitin reaction roughly paralleled the agglutination, although the two did not necessarily occur together. Myers and Keefer (1934) confirmed the fact that the blood of patients recovering from hæmolytic streptococcal infections contains antistreptolysin in high titre, and that, while comparable titres are commonly found in patients with acute rheumatism, no such titre was found in patients with rheumatoid arthritis. On the other hand, antistreptolysin titres definitely above normal were found by Blair and Hallman (1935) in about one-third of the sera from similar patients. It has been shown that antifibrinolysin can 
be demonstrated in the blood of some patients recovering from hæmolytic streptococcal infection (Tillett and Garner (1933), Tillett, Edwards and Garner (1934), Myers, Keefer and Holmes (1935), etc.). It is now generally agreed that antifibrinolysin similarly occurs in the blood of a considerable proportion of patients with acute rheumatism (Hadfield, Magee and Perry (1934), McEwen, Alexander and Bunim (1935), Myers, Keefer and Holmes (1935), etc.). In view of the occurrence of streptococcal agglutinins in the patients with rheumatoid arthritis already described, it was decided to investigate a series of patients with this disease for the presence of antifibrinolysin. Antifibrinolysin estimations were therefore made on the sera of thirty-three patients with typical rheumatoid arthritis. All the patients in this series had been ill for more than six months, and many for several years. Repeated observations were made during and after treatment with gold salts, and in all 171 observations were made on the thirty-three patients, only eight patients being tested once only. The technique was similar to that described by Tillett and Garner (1933), and every plasma was tested against four different strains of streptococci, as described by Perry (1939). Of the 171 observations, 161 fell within the normal range. In five tests on two of the patients normal at other times a doubtful degree of resistance of fibrinolysin was found (four times in one patient and once in the other). Definite resistance to fibrinolysin occurred only five times: twice in a patient normal at four other times and three times in a patient normal on eight other occasions.

Since spondylitis ankylopoietica presents many features in common with rheumatoid arthritis, blood from eight typical examples of this disease was also investigated, forty-nine observations being made on the eight patients. Of these, seven gave negative reactions whenever the blood was tested, and one gave a positive reaction when first examined, but was normal on two subsequent occasions.

These results are in striking contrast to those found in acute rheumatism, in the active stage of which antifibrinolysin was demonstrated in 75 per cent. of forty-four patients (Perry, 1939); and they show that streptococcal antifibrinolysin is not found at all commonly in the blood of patients suffering from rheumatoid arthritis or spondylitis ankylopoietica. 


\section{SUMmaRY}

Antifibrinolysin determinations were carried out on the plasma of thirty-three patients with rheumatoid arthritis. Definite resistance to fibrinolysin was found as a transient phenomenon in two of the patients. Similar tests were performed forty-nine times in eight patients with spondylitis ankylopoietica. A transient rise in the antifibrinolysin titre was found in one patient only.

Thanks are due to Mr. W. Emery and Mr. E. Guise for technical assistance, and to the Colston Research Society of the University of Bristol for a grant which made this investigation possible.

\section{REFERENCES}

Blair, J. E., and Hallman, F. E. (1935): Journ. Clin. Invest., 14, 505.

Cecil, R. L., Nicholls, E. E., and Stainsby, W. J. (1931): Amer. Journ. Med. Science, 181, 12.

Cox, K. F., AND HmL, D. F. (1934): Arch. Int. Med., 54, 27.

Dawson, M. H., Olmstead, M., and Boots, R. H. (1931): Proc. Soc. Exp. Biol. and Med., 28, 421.

Dawson, M. H., Olmstead, M., and Boots, R. H. (1932): Journ. Immun., 23, 187.

Hadfield, G., Magee, V., and Perry, C. B. (1934): Lancet, 1, 834.

Keefer, C. S., Myers, W. K., and OpPeL, T. W. (1933): Journ. Clin. Invest., 12, 267.

McEwen, C., Auexander, M. A., and Bunim, J. J. (1935): Journ. Lab. and Clin. Med., 21, 465.

McEwen, C., Chasis, H., and Alexander, R. C. (1935): Proc. Soc. Exp. Biol. and Med., 33, 133.

MYers, W. K., AND KeEFer, C. S. (1934): Journ. Clin. Invest., 13, 155.

Myers, W. K., Keefer, C. S., and Holmes, W. F. (1935): Journ. Clin. Invest., 14, 119.

Neil, M. S., AND Hartung, E. F. (1937): Journ. Lab. and Clin. Med., 22,881 .

Nicholls, E. E., ANd Stannsby, W. J. (1931): Journ. Clin. Invest., 10, 323.

Nicholls, E. E., and Stainsby, W. J. (1933): Journ. Clin. Invest., 12, 505.

Perry, C. B. (1939): Arch. Dis. Child., 14, 32.

Tillett, W. S., AND Garner, R. L. (1933): Journ. Exp. Med., 58, 485.

Tillett, W. S., Edwards, L. B., AND Garner, R. L. (1934) : Journ. Clin. Invest., 13, 47. 